\title{
Sternotherus carinatus (Gray 1856) - Razorback Musk Turtle, Razor-Backed Musk Turtle
}

\author{
Peter V. Lindeman ${ }^{1}$ \\ ${ }^{1}$ Department of Biology and Health Services, 150 Cooper Hall, \\ Edinboro University of Pennsylvania, Edinboro, Pennsylvania 16444 USA \\ [plindeman@edinboro.edu]
}

Summary. - Sternotherus carinatus (Family Kinosternidae) is a poorly-known species by the standards of the North American chelonian literature. It inhabits medium to large streams and associated aquatic habitats in portions of six states of the south-central USA. Little note has been made of the species being a conservation concern, and indeed, it appears abundant and stable in parts of its range. Further studies on abundance in different types of habitats, response to river impoundments, and the demographic impact of collection for the pet trade are necessary to determine whether there is a need for conservation actions regarding this species. A study of interdrainage genetic variation would also be useful for the conservation of this species.

DistRibution. - USA. Restricted to six south-central states, from the Brazos River drainage in eastern Texas eastward to the Pascagoula River drainage in southeastern Mississippi and Mobile County in southwestern Alabama.

Synonymy. - Aromochelys carinata Gray 1856, Aromochelys carinatum, Aromochelys carinatus, Goniochelys carinata, Cinosternum carinatum, Kinosternon carinatum, Sternotherus carinatus, Sternothaerus carinatus, Kinosternon carinatus, Goniochelys triquetra Agassiz 1857.

SubSPECIES. - None recognized.

STATUS. - IUCN 2007 Red List: Not Listed (= Least Concern, LR/lc) (assessed 1996, needs updating); CITES: Not Listed; US ESA: Not Listed.

Taxonomy. - Sternotherus carinatus was described as Aromochelys carinata by Gray (1856), based on four syntypes housed in the British Museum of Natural History and collected in "Louisiana," later restricted to "vicinity of New Orleans" (Schmidt 1953). No subspecies have been designated for $S$. carinatus, nor have geographic trends in morphology or genetic variation been analyzed. Iverson's $(1991,1998)$ total-evidence analyses of morphological and molecular data sets found $S$. carinatus to be sister taxon to a $S$. minor plus $S$. depressus clade, with this clade of three

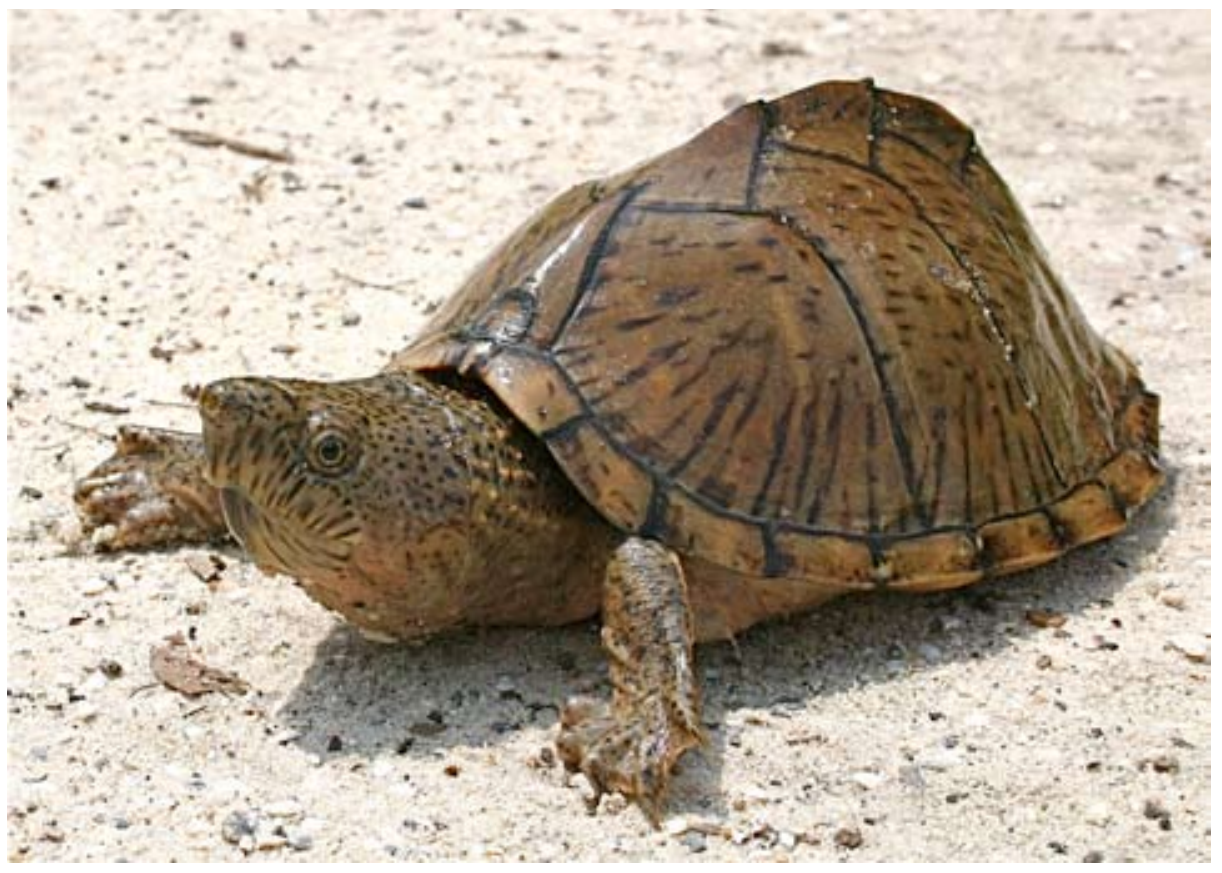

Figure 1. Adult Sternotherus carinatus on a beach on the Pascagoula River, Mississippi. Photo by Robert C. Thomson. 


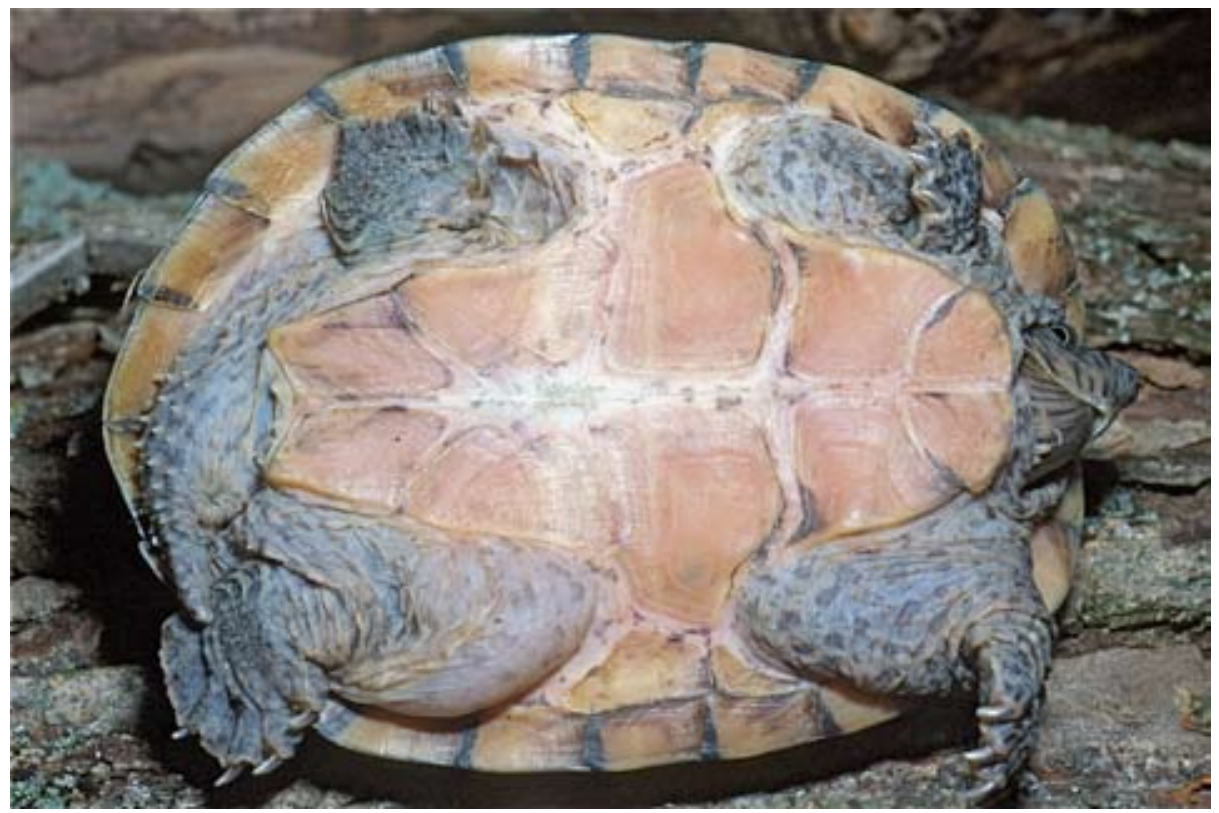

Figure 2. Adult Sternotherus carinatus from Louisiana. Photo by James H. Harding.

species being sister to the remaining congener, S. odoratus. Iverson (1991) followed Seidel et al. (1986) in placing Sternotherus in synonymy with Kinosternon, using Kinosternon carinatum for the razorback musk turtle. The change was suggested due to a lack of recognized synapomorphies for the members of Sternotherus, but Iverson (1998) later reversed his decision based on phylogenetic analysis of a larger data set and has used the name Sternotherus carinatus in more recent publications (e.g., Iverson 2002).

Description. - The scutes of the carapace of Sternotherus carinatus overlap one another at their posterior edges; marginals number 11 on each side of the nuchal scute and protrude, creating a weakly serrated carapace. Carapacial scutes are light brown with dark streaks that may be lost with age. The plastron is reduced and weakly hinged. The species is distinguished from congeners by the following combination of characters: 1) a peaked, exceptionally high-domed shell;

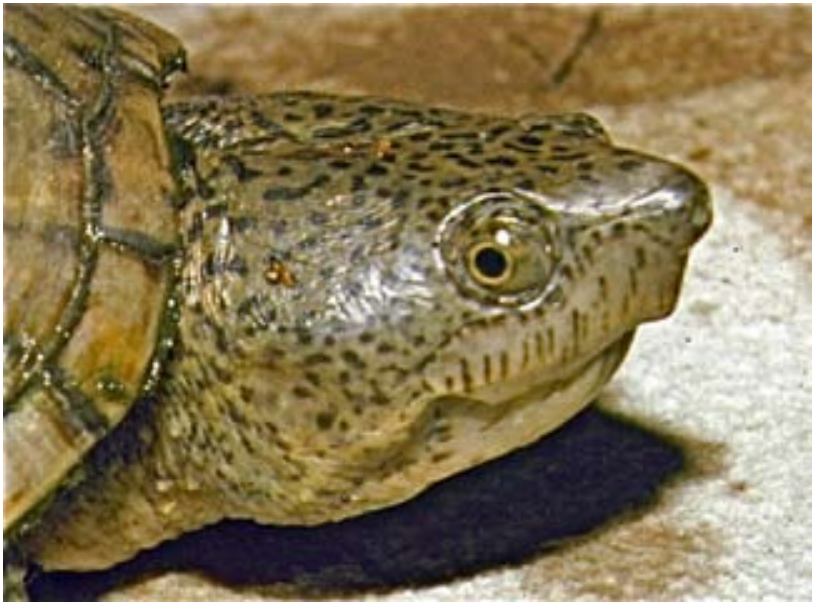

Figure 3. Adult Sternotherus carinatus from Arkansas. Photo by Stanley E. Trauth.
2) presence of a pair of barbels on the chin but not on the neck; 3) presence of distinct small dark spots and absence of striping on the light brown to pink head and limbs; and 4) (usually) lack of a gular scute, leaving 10 plastral scutes rather than 11. The skull of S. carinatus is distinct from those of its two closest relatives, S. minor and S. depressus, based on a more pointed supraoccipital, presence of a prominent

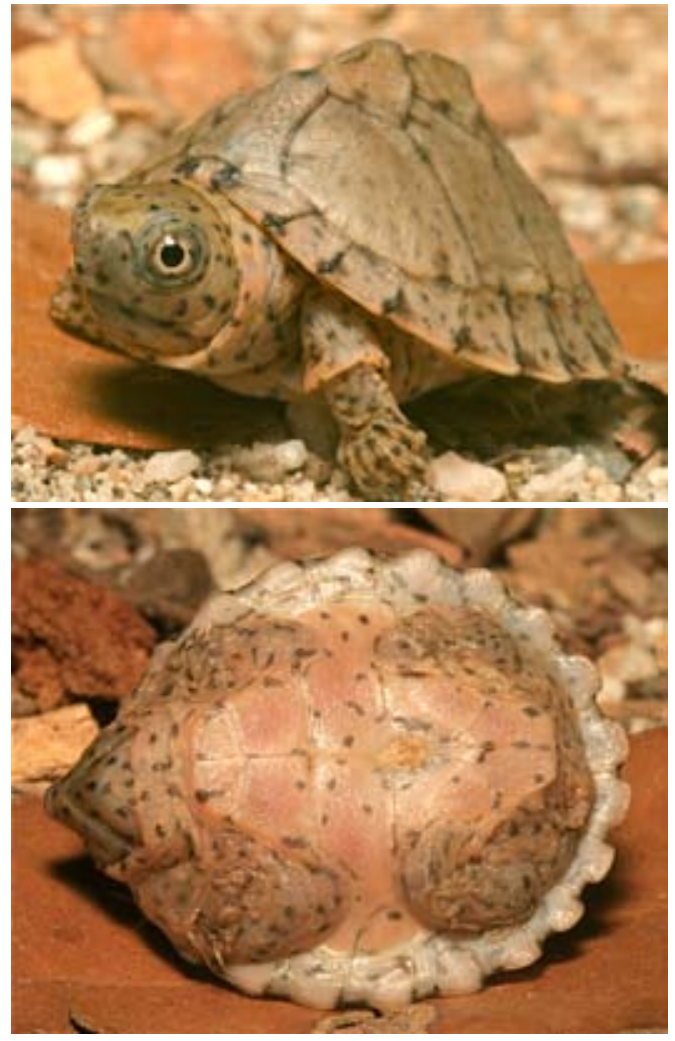

Figure 4. Hatchling Sternotherus carinatus from McCurtain County, Oklahoma. Photos by R.D. Bartlett. 


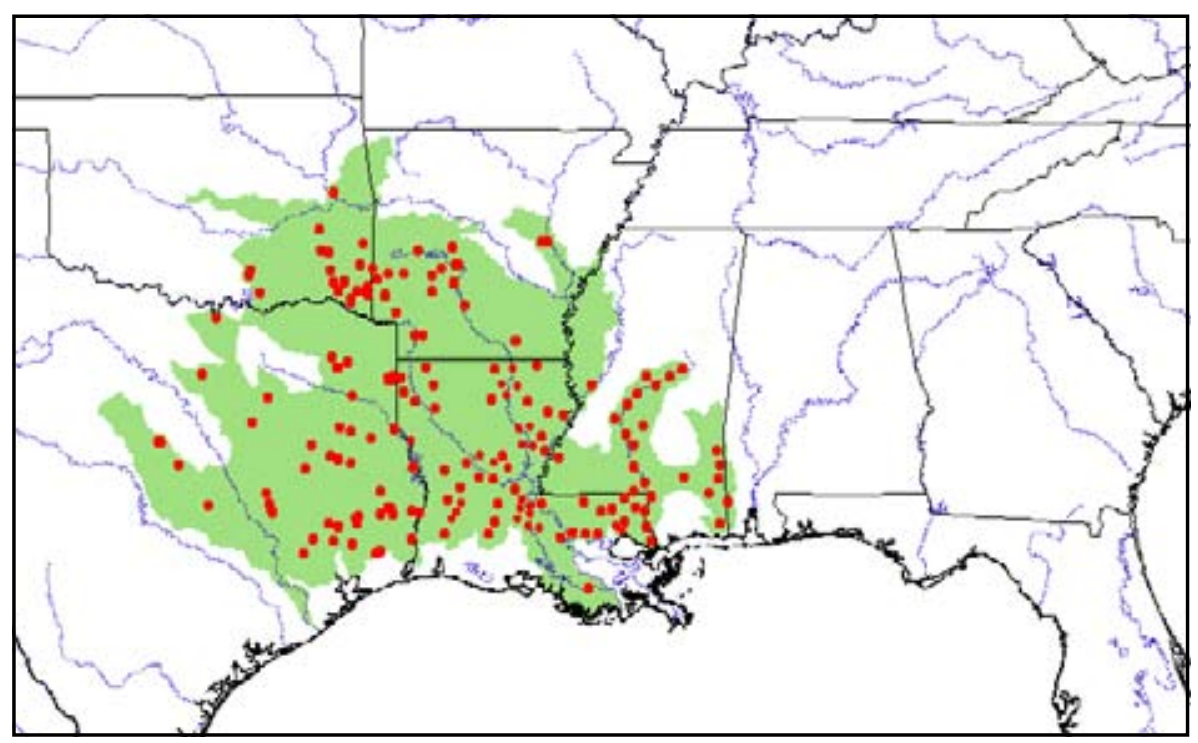

Figure 5. Distribution of Sternotherus carinatus in southeastern USA. Red points = museum and literature occurrence records based on published records plus more recent and author's data; green shading = projected distribution based on GIS-defined hydrologic unit compartments (HUCs) constructed around verified localities and then adding HUCs that connect known point localities in the same watershed or physiographic region, and similar habitats and elevations as verified HUCs (Buhlmann et al., unpubl. data), and adjusted based on author's data.

boss on the underside of the squamosal, and a more distinct spinous process of the pterygoid (Tinkle 1958).

Conant and Collins (1991) give the record size as 176 $\mathrm{mm}$ carapace length $(\mathrm{CL})$, but there is a larger specimen from Hot Springs, Arkansas (209 mm CL, CRI 7609; P. Pritchard, pers. comm.). There appears to be geographic variation in body size, with maximum CL being $155 \mathrm{~mm}$ in an Arkansas population, $128 \mathrm{~mm}$ in an Oklahoma population, and 144 $\mathrm{mm}$ in a series from Gulf Coastal regions (Tinkle 1958; Iverson 2002). Hatchlings are $25-28 \mathrm{~mm}$ in CL and weigh 3-4 g (Iverson 2002). There is little sexual size dimorphism, although males may reach slightly larger sizes (Tinkle 1958; Iverson 2002). Males are recognized by their longer tails but other sexual differences are lacking (Tinkle 1958).

Distribution. - Sternotherus carinatus is native to six states of the south-central United States. It occurs nearly statewide in Louisiana (excluding southern coastal regions), as well as in southern Mississippi, southern Arkansas, southeastern Oklahoma, eastern Texas, and a small portion of southwestern Alabama (Iverson 1992; Blankenship et al. 1995). From west to east along the coast of the Gulf of Mexico, major drainages occupied by the species include: 1) the Brazos, Trinity, and Neches-Sabine river drainages of Texas; 2) the Calcasieu and Mississippi river drainages of Louisiana (extending up from the latter into the Ouachita, Red, and Canadian drainages of southwestern Arkansas and southeastern Oklahoma, and into the Yazoo drainage of westcentral Mississippi); and 3) the Pearl and Pascagoula drainages of southeastern Mississippi. The range extends into southwestern Alabama in the Escatawpa River, a tributary of the lower Pascagoula River, where two specimens were recently taken (Blankenship et al. 1995; Godwin 2004).

Habitat and Ecology. - Sternotherus carinatus is typically found in medium to large flowing streams where the substrate is gravel, sand, or cobble, but also occurs in oxbow lakes and floodplain swamps (Tinkle 1958; Mahmoud 1969; Dundee and Rossman 1989; Trauth et al. 2004). The Escatawpa population in Alabama occurs in a blackwater stream (Godwin 2004). Submerged and emergent deadwood is likely an important habitat feature. Basking behavior is more pronounced in $S$. carinatus than in other kinosternid species (Boyer 1965; Lindeman 1993, 1996). Individuals show a proclivity for basking high above the water on narrow, steeply-angled deadwood substrates and may avoid substrates occupied by other turtles (Lindeman 1996). In the water, the animal is a bottom walker that uses crevices under submerged deadwood or rocks for hiding (Mahmoud 1969; Jackson 1988).

Low trapping success has been commented upon by Cagle and Chaney (1950), Tinkle (1958), and Trauth et al. (2004), but interpreted as a lack of attraction to bait, rather than natural rarity of the species. Greater relative abundance of the species occurs in sampling when using unbaited fyke nets (Vogt 1980), night capture (Chaney and Smith 1950; J. Iverson, pers. comm.), or spotting-scope counts of basking turtles (Lindeman 1993, 1996).

Courtship of $S$. carinatus and three other kinosternid species was described by Mahmoud (1967), who noted that there were few interspecific differences; observations concerning S. carinatus comprised only 5\% of all courtship attempts observed, however. The male initiates courtship by probing first at the female's cloaca with his snout and then at her bridge, near the site of musk glands. If a chase ensues, the male then attempts to use his mouth to grasp the female by the head. The male then mounts the female and holds her tail to one side between two rough patches on one of his knees.

Growth in $S$. carinatus follows the pattern typical of temperate-zone freshwater turtles, in that it is most rapid in 
young animals and gradually slows in rate as the turtle ages and grows larger (Tinkle 1958; Mahmoud 1969; Iverson 2002). Maturity is reached at $80-120 \mathrm{~mm} \mathrm{CL}$ at $4-8$ yrs of age (Tinkle 1958; Mahmoud 1967; Iverson 2002).

Gonadal cycles of $S$. carinatus were described by Mahmoud and Klicka (1972) and Iverson (2002). Male testes are largest in July and August, coinciding with peak sperm production. In females, follicle development occurs slowly in the fall and accelerates in spring and early summer.

Reproduction has been studied via specimen dissections for populations in Oklahoma, Arkansas, and a variety of sites along the Gulf Coast (Tinkle 1958; Mahmoud and Klicka 1972; Iverson 2002). Clutch size ranges from 1-7 with reported population means of 2.3 (Oklahoma) and 3.8 (Arkansas; Iverson 2002). Apparently, 2-3 clutches per season are typical (Iverson 2002). Nesting occurs in May, June, and early July in Arkansas and Oklahoma, but may begin earlier further south (Iverson 2002). Eggs are elliptical and brittle-shelled, with lengths from 24.0-34.6 mm and widths from 14.4-18.2 mm (Mahmoud and Klicka 1972; Iverson 2002). Both clutch size and egg size are positively correlated with female body size (Iverson 2002).

Temperature-dependent sex determination occurs in S. carinatus via Pattern II, in which males are produced at intermediate temperatures and females at cooler and warmer extremes (Ewert and Nelson 1991). For 24 total eggs incubated at constant temperatures, sex ratios were $100 \%$ males at $27^{\circ} \mathrm{C}, 100 \%$ females at both 22.5 and $30^{\circ} \mathrm{C}$, and $80 \%$ females at $25^{\circ} \mathrm{C}$.

Major prey taxa of $S$. carinatus, in approximate order of importance, include aquatic insects, snails, clams, and crayfish (Tinkle 1958; Mahmoud 1968). The importance of mollusks in the diet increases in larger specimens (Tinkle 1958).

Parasites of $S$. carinatus have been described in Ernst and Barbour (1972). These include a blood protozoan, several species of trematodes, and a nematode. The alligator snapping turtle, Macrochelys temminckii, is likely an important predator of $S$. carinatus, which retreated from the source of water taken from a tank holding a M. temminckii in a controlled laboratory setting (Jackson 1990).

Population Status. - Status of Sternotherus carinatus populations is little known due to a relative lack of studies that have focused on the ecology and natural history of the species, particularly in the more recent literature. Observations suggest it is an abundant species in several parts of its range. It has long been the most frequently encountered turtle species in Caddo Lake, Texas (Red River drainage; J. Dixon, pers. comm.). Also, it is considered abundant in the Pearl River drainage (Lindeman 1996, 1998; D.Collins, pers. comm.), an oxbow lake of the Neches River, Texas, known as Joe's Lake (J. Dixon, pers. comm.), and in rocky streams near the Arkansas-Oklahoma border (J. Iverson, pers. comm.).

Few studies have included data on population status of $S$. carinatus and even fewer involve populations that have been revisited over time. In the only published estimate of density for the species, Mahmoud (1969) estimated a density of 229 individuals/ha for the Mountain Fork River in southeastern Oklahoma, which Iverson (1982) calculated to be a biomass of $14.35 \mathrm{~kg} / \mathrm{ha}$. The only comparisons of historical data with more recent data have been of abundance relative to other turtle species in two river drainages in southern Mississippi.Avariety of trapping studies conducted between the late 1940s and 1978 were compared with spotting-scope surveys conducted in 1994-95 (Lindeman 1996, 1998). Relative abundance data compared favorably for the Pearl River drainage; however, data were suggestive of a possible sharp decline in relative abundance in the Pascagoula drainage, where numbers of all turtle species were considerably lower. Several threats, including toxic pollutants, snagging of deadwood used for basking, sedimentation, sand and gravel mining, and impoundments affect sympatric turtle species of the Pascagoula drainage (Stewart 1990). The differences in survey methodology and specific sites surveyed make it unclear how accurate the comparisons were, however.

Threats to Survival. - Forms of habitat destruction relevant to the status of $S$. carinatus have not been specified in the literature on the species. Nevertheless, it is likely that the species is susceptible to some of the same threats faced by its congener, the federally-listed flattened musk turtle ( $S$. depressus), and other freshwater turtles of the southeastern United States: sedimentation, snagging operations that remove deadwood, sand and gravel mining, and toxic pollutants (Dodd 1990; Stewart 1990; Lindeman 1999). While Dodd (1990) found river impoundments to represent habitat lost to $S$.depressus, contributing to its fragmented distribution, the reported abundance of $S$. carinatus in reservoirs and oxbow lakes suggests it may be somewhat more adapted to lentic habitats (Lindeman 1996, 1998; Iverson 2002; J. Dixon, pers. comm.).

A recent quantitative ranking of non-marine turtle species in the U.S., with regard to their vulnerability to the commercial pet trade, listed $S$. carinatus as the fifth most vulnerable species in the United States (Reed and Gibbons 2004). This ranking appears to have been influenced more by the species' demography and small range size than its value to dealers. Reed and Gibbons (2004) found that two of 24 online reptile dealers found to deal in live turtles sold wild-caught S. carinatus, for \$15-16 US. Recent reptile shows reportedly have had large numbers of hatchlings on exhibit, suggesting captive propagation of animals for the pet trade (D. Boyer, pers.comm.). While such propagation could theoretically take pressure off wild populations, it could also fuel an increased desire for the species that could result in increased take from the wild. Wanton killing also occurs; Mahmoud (1969) described a case of two fishermen in Oklahoma killing 51 S. carinatus within a two-hour period in 1959.

Conservation Measures Taken. - Sternotherus carinatus is not presently listed under CITES Appendices, by the IUCN Red List, or under the U.S. Endangered Species Act, nor is it state-listed in any of its six range states. Under the Natural Heritage Commission (NHC) rankings used by The Nature Conservancy, the species is listed as G1 (secure), with listings of $\mathrm{S} 1$ (critically imperiled; $<5$ occurrences) in 
Alabama and S3 (rare or uncommon; 20-100 occurrences) in Arkansas. The Alabama listing is undoubtedly due to the position of the recently-discovered sole locality within the state, on the species' range periphery (Blankenship et al. 1995; Godwin 2004). The Arkansas listing is based on low frequency of encounters compared to other kinosternids in the state. The species had been included on the Arkansas NHC tracking list, but was never considered a high inventory priority and has recently been dropped from that list (C. Osborne, pers. comm.).

Although no habitat preserves have been designated specifically for $S$. carinatus, populations occur in habitats located within eight national forests, one state wilderness area, 17 national wildlife refuges, one national preserve, a Ramsar Convention Wetland of International Importance, and two private nature preserves. National forests include: 1) the Ouachita National Forest (Arkansas and Oklahoma); 2) Kisatchie National Forest (Louisiana); 3) Bienville and De Soto National Forests (Mississippi); and 4) Angelina, Davy Crockett, Sabine, and Sam Houston National Forests (Texas). Within De Soto National Forest, watershed habitat of twolarge tributaries of the Pascagoula drainage is protected by the Leaf River Wilderness Area (402 ha) and Black Creek Wilderness Area (2045 ha). Within Kisatchie National Forest, Bayou Cypre is protected by Kisatchie Hills Wilderness Area (21,437 ha). The state of Oklahoma manages the McCurtain County Wilderness Area (5703 ha) on the upstream shoreline of Broken Bow Lake, an impoundment of Mountain Fork River.

National Wildlife Refuges (NWR) known or likely to be inhabited by S.carinatus include: 1) Felsenthal,Pond Creek, and White River NWR in Arkansas; 2) Atchafalaya, Bayou Cocodrie, Black Bayou, Cat Island, Catahoula, D'Arbonne, Grand Cote, Handy Brake, Lake Ophelia, Tensas River, and Upper Ouachita NWR in Louisiana; 3) Bogue Chitto NWR in Louisiana and Mississippi; 4) Little River NWR in Oklahoma; and 5) Trinity River NWR in Texas. The Big Thicket National Preserve is managed by the U.S. National Park Service and protects over $65 \mathrm{~km}$ of riverbank along the Neches River in east Texas.

Among the many state parks and state wildlife lands containing $S$. carinatus habitat, one of the most important is Caddo Lake State Park and Wildlife Management Area in Texas, the centerpiece of an 8382 ha Wetland of International Importance under the Ramsar Convention. Finally, the Mississippi chapter of The Nature Conservancy protects two tracts of land, the Herman Murrah preserve (648 ha) and the Charles Deaton preserve (1340 ha), at the confluence of the Leaf and Chickasawhay rivers on the Pascagoula drainage. The organization is also actively engaged in coordinating watershed conservation on the mainstem Pascagoula River and on the lower Pearl River.

According to online 2008 data of the International Species Inventory System (www.isis.org), captive S. carinatus are held by 12 institutions in the United States, the Ueno Zoological Gardens in Tokyo, Japan, and the ParcZoologique d'Amnéville in France. Total numbers are 7 males, 14 females, and 28 juveniles (7.14.28). Only four institutions have potential breeding pairs. The largest collection is at the Tennessee Aquarium (2.8.14). All of the original individuals at the Tennessee Aquarium were collected from the lower Pearl River in the early 1990s (D. Collins, pers. comm.) and they produced the original three animals of the San Diego Zoo collection (D. Boyer, pers. comm.).

Conservation Measures Proposed. - No threatened listing under the IUCN Red List or the U.S. Endangered Species Act is recommended at this time, as $S$. carinatus appears secure throughout much of its geographic range. Specific conservation management actions for the species and its habitat are not warranted at this time, given its apparent secure status in much of its range and numerous protected habitats. However, there is a need for more general ecological and population status information on the species.

Captive Husbandry. - The only published observations on captive husbandry of $S$. carinatus involve a male and two females kept on a natural cycle of illumination by Becker (1992). One female mated several times with the male and laid two clutches, of two and four eggs, 29 days apart. With incubation at warm temperatures $\left(28-30^{\circ} \mathrm{C}\right)$ and high humidity, all six eggs hatched, 109-139 days following oviposition. Hatchlings appeared to be of normal health and weighed 3.4-4.2 g. Adults and hatchlings were maintained on a diet of commercial turtle chow and a gelatin prepared with beef and chicken hearts, sardines, bananas, apples, spinach, rice, tomatoes, and domestic chicken eggs with shells.

The species has bred prolifically in the Tennessee Aquarium's large Delta Exhibit, which is maintained on a seasonal pattern of fluctuation in water temperature (D. Collins, pers. comm.). Mating and egg production occur at the San Diego Zoo without any special encouragement for breeding. Egg deposition has been recorded in a fern planter, access to which requires a nearly vertical climb high out of the exhibit by the female (D. Boyer, pers. comm.). Eggs produced in both institutions are presently not incubated to avoid producing a surplus of captive animals (D. Collins, pers. comm.; D. Boyer, pers. comm.).

Current Research. - Very little recent research has been focused on $S$. carinatus: collection of specimens for Iverson's (2002) reproductive studies was conducted between 1984 and 1997, while spotting-scope surveys by Lindeman (1996) were conducted in 1994 and 1995. While S.carinatus is regarded as a species of medium to large streams of the western Gulf of Mexico coastal area, the extent of its use of smaller tributary streams, backwater sloughs, and oxbow lakes is poorly understood. Such habitats can be vital safe havens with regard to some of the threats to large-river communities (e.g., Lindeman 1998). A better understanding of use of these habitats would be information vital to any future assessment of or attempt to improve upon the conservation status of the species. The species' response to river impoundment is also poorly understood.

Where collection for the pet trade is known to occur, studies of local impacts on abundance would be beneficial in testing the analysis of Reed and Gibbons (2004), which suggested high vulnerability of the species to commercial trade. 
There is no information available on geographic variation in morphology or genetic phylogeography of $S$. carinatus. Given its distribution across multiple drainage basins, genetic and morphological analyses of geographic variation in the species, such as those that have been conducted for two congeners (Iverson 1977; Reynolds and Seidel 1983; Walker et al. 1995, 1997), would provide useful information for conservation and management of this species.

Acknowledgments. - For sharing their unpublished observations, I thank D. Boyer, D. Collins, J. Dixon, J. Iverson, P. Pritchard, and C. Osborne.

\section{LITERATURE CITED}

Agassiz, L. 1857. Contributions to the Natural History of the United States of America, Vol. I. Little, Brown and Company, Boston, MA. 452 pp.

BECKER,H.1992. Beobachtungen bei derHaltung and Nachzucht von Sternotherus carinatus (Gray, 1856). Salamandra 28:9-13.

Blankenship,E.L.,Bailey,M.A.,Schnuelle, K., andHauge,B.1995. Sternotherus carinatus (razorback musk turtle). Herpetological Review 26:106-107.

BOYER, D.R. 1965. The ecology of the basking habit in turtles. Ecology 46:99-118.

CAGLE,F.R., ANDCHANEY,A.H.1950.Turtle populations in Louisiana. American Midland Naturalist 43:383-388.

Chaney, A., and Smith, C.L. 1950. Methods for collecting map turtles. Copeia 1950:323-324.

Conant, R., And Collins, J.T. 1991. A Field Guide to Reptiles and Amphibians of Eastern and Central North America, $3^{\text {rd }}$ ed. Houghton Mifflin, Boston, MA. 450 pp.

DoDD, C.K., JR. 1990. Effects of habitat fragmentation on a streamdwelling species, the flattened musk turtle Sternotherus depressus. Biological Conservation 54:33-45.

Dundee, H.A., and Rossman, D.A. 1989. The Amphibians and Reptiles of Louisiana. Louisiana State University Press, Baton Rouge, LA. 300 pp.

ERnst, C.H., AND R.W. Barbour. 1972. Turtles of the United States. University Press of Kentucky, Lexington. 347 pp.

EwERT, M.A., AND Nelson, C.E. 1991. Sex determination in turtles: diverse patterns and some possible adaptive values. Copeia 1991:50-69.

GoDwIN,J.C.2004.Razor-backed musk turtle Sternotherus carinatus Gray. In: Mirarchi, R.E., Bailey, M.A., Haggerty, T.M., and Best, T.L.(Eds.).Alabama Wildlife Volume Three: Imperiled Amphibians, Reptiles, Birds, and Mammals. The University of Alabama Press, Tuscaloosa, AL, pp 79-80.

GraY, J.E. 1856. On some new species of freshwater tortoises from North America, Ceylon and Australia, in the collection of the British Museum. Proceedings of the Zoological Society of London 1855[1856](23):197-202

IvERSON, J.B. 1977. Geographic variation in the musk turtle, Sternotherus minor. Copeia 1977:502-517.

IVERSON,J.B.1982.Biomass in turtle populations: a neglected subject. Oecologia 55:69-76.

IVERSON,J.B. 1991.Phylogenetic hypotheses for the evolution of modern kinosternine turtles. Herpetological Monographs 5:1-27.

Iverson, J.B. 1992. A Revised Checklist with Distribution Maps of the Turtles of the World. Privately Published, Richmond, Indiana. $363 \mathrm{pp}$.

IVERSON, J.B. 1998. Molecules, morphology, and mud turtle phylogenetics (family Kinosternidae). Chelonian Conservation and Biology 3:113-117.

IvERSON, J.B. 2002. Reproduction in female razorback musk turtles
(Sternotherus carinatus: Kinosternidae). Southwestern Naturalist 47:215-224

JACKSON,J.F.1988. Crevice occupation by musk turtles: taxonomic distribution and crevice attributes. Animal Behaviour 36:793-801.

JACKSON, J.F. 1990. Evidence for chemosensor-mediated predator avoidance in musk turtles. Copeia 1990:557-560.

LiNDEMAN, P.V. 1993. Aerial basking by hatchling freshwater turtles. Herpetological Review 24:84-87.

LiNDEMAN, P.V. 1996. Distribution, relative abundance, and basking ecology of the razorback musk turtle, Kinosternon carinatum, in the Pearl and Pascagoula river drainages. Herpetological Natural History 4:23-34.

LiNDEMAN,P.V.1998. Of deadwood and map turtles: an analysis of species status for five species in three river drainages using replicated spotting-scope counts of basking turtles. Linnaeus Fund Research Report. Chelonian Conservation and Biology 3:137-141.

LindEMAN, P.V. 1999. Surveys of basking map turtles Graptemys spp. in three river drainages and the importance of deadwood abundance. Biological Conservation 88:33-42.

MAHMOUD,I.Y. 1967. Courtship behavior and sexual maturity in four species of kinosternid turtles. Copeia 1967:314-319.

MaHmoud, I.Y. 1968. Feeding behavior in kinosternid turtles. Herpetologica 24:300-305.

MAHMOUD,I.Y. 1969. Comparative ecology of the kinosternid turtles of Oklahoma. Southwestern Naturalist 14:31-66.

MAHMOUd, I.Y., AND KLICKA, J. 1972. Seasonal gonadal changes in kinosternid turtles. Journal of Herpetology 6:183-189.

REED, R.N., AND GIBBONS, J.W. 2004. Conservation status of live U.S. nonmarineturtles in domestic and international trade. Unpublished report to the U.S. Fish and Wildlife Service.

REYNOLDS, S.L., ANDSEIDEL,M.E. 1983. Morphological homogeneity in the turtle Sternotherus odoratus (Kinosternidae) throughout its range. Journal of Herpetology 17:113-120.

ScHMIDT, K.P. 1953.ACheck List of North AmericanAmphibians and Reptiles, $6^{\text {th }}$ ed. Chicago University Press, Chicago, IL. 280 pp.

SEIDEL, M.E., Iverson, J.B., AND AdKINs, M.D. 1986. Biochemical comparisons and phylogenetic relationships in the family Kinosternidae (Testudines). Copeia 1986:285-294.

STEWART, J.H. 1990. Endangered and threatened wildlife and plants; proposed threatened status for the yellow-blotched map turtle, Graptemys flavimaculata. Federal Register 55:28570-28573.

TinkLE,D.W. 1958. The systematics and ecology of the Sternothaerus carinatus complex (Testudinata: Chelydridae). Tulane Studies in Zoology 6:3-56.

Trauth, S.E., Robison, H.W., and Plummer, M.V. 2004. The Amphibians and Reptiles of Arkansas. University of Arkansas Press, Fayetteville, AR. 382 pp.

Vogt, R.C. 1980. New methods for trapping aquatic turtles. Copeia 1980:368-371.

Walker, D., Burke, V.J., Barák, I., AND Avise, J.C. 1995. A comparison of mtDNA restriction sites vs. control region sequences in phylogeographic assessment of the musk turtle (Sternotherus minor). Molecular Ecology 4:365-373.

Walker, D., Nelson, W.S., Buhlmann, K.A., and Avise, J.C. 1997. Mitochondrial DNA phylogeography and subspecies issues in the monotypic freshwater turtle Sternotherus odoratus. Copeia 1997:16-21.

\section{Citation Format for this Account:}

Lindeman, P.V. 2008. Sternotherus carinatus Gray 1856 - razorback musk turtle, razor-backed musk turtle. In: Rhodin, A.G.J., Pritchard, P.C.H., van Dijk, P.P., Saumure, R.A., Buhlmann, K.A., and Iverson, J.B. (Eds.). Conservation Biology of Freshwater Turtles and Tortoises: A Compilation Project of the IUCN/ SSC Tortoise and Freshwater Turtle Specialist Group. Chelonian Research Monographs No. 5, pp. 012.1-012.6, doi:10.3854/ crm.5.012.carinatus.v1.2008, http://www.iucn-tftsg.org/cbftt/. 